\title{
IDŐJÁRÁS
}

Quarterly Journal of the Hungarian Meteorological Service

Vol. 123, No. 4, October-December, 2019, pp. 487-500

\section{Change of maximum snow cover depth in Poland - trends and projections}

\section{Malgorzata Szwed $^{1^{*}}$, Andreas Dobler ${ }^{2}$, Abdelkader Mezghani ${ }^{2}$, and Tuomo Mikael Saloranta ${ }^{3 * *}$}

${ }^{1}$ Institute for Agriculture and Forest Environment of Polish Academy of Sciences Bukowska 19, 60-809 Poznań, Poland

${ }^{2}$ The Norwegian Meteorological Institute Henrik Mohns plass 1, 0313 Oslo, Norway

${ }^{3}$ The Norwegian Water Resources and Energy Directorate, Middelthuns gate 29, 0368 Oslo, Norway

*Corresponding Author e-mail: mszwed@man.poznan.pl

**Contact person for the seNorge model,e-mail: tus@nve.no

(Manuscript received in final form December 31, 2018)

\begin{abstract}
The present paper examines the observed variability of maximum depth of snow cover in Poland and its projections for near (2021-2050) and far (2071-2100) future. The study makes use of a set of 43 time series of observation records from stations in Poland, from 1951 to 2013. For the future, two downscaling experiments were conducted with the aim of producing reliable high-resolution climate projections of precipitation and temperature for Poland. The results of these projections were used as the input data to the seNorge snow model in order to transform bias-adjusted daily temperature and precipitation into daily snow conditions. Observed behavior of time series of snow is complex and not easy to interpret. The changes (if any) are dominated by strong inter-winter and intra-winter variability, rendering trend detection difficult. Projected seasonal snow cover depth (for winter as well as spring and autumn) as simulated by the snow model for the near and far future show decreases. The rate of decreasing maximum snow depth is expected to at least double by $2071-2100$.
\end{abstract}

Key-words: snow cover, observations, projections, snow model, Poland 


\section{Introduction}

In the conditions of overwhelming warming, intuitively, one can expect smaller snowfalls (by virtue of the increase in liquid winter precipitation due to warming) and, consequently, occurrence of a reduced snow cover (both shorterlying and thinner). Yet, there is a strong natural variability of snow cover depth, also between consecutive winters or consecutive intervals within a single winter. Snow cover is, in fact, a very sensitive variable, because its formation and maintenance in the landscape depends on many factors.

In any case, thinking about global warming, one usually thinks of average conditions getting warmer. However it does not mean that in the future in the middle of a warm and snowless winter, there is no chance for one or a few frosty and snowy spells. In this context, it seems interesting to analyze what changes (if any) in the snow cover depth have been observed in past-to-present and what projections are developed for the future.

\section{Data and methodology}

For analyzing the present situation, the study makes use of a set of 43 time series of observation records from stations in Poland, from 1951 to 2013. The data was provided by the Polish Institute of Meteorology and Water Management - State Research Institute (Polish acronym: IMGW-PIB). The basic criteria for selection of stations were: (i) the length of the available time series of record, and (ii) the spatial distribution of stations with the goal of covering the whole territory of Poland and its climate regions, in a possibly uniform way. The studied data started on October 1, 1951 (38 meteorological stations) or later (5 stations) and continued until December 31, 2013. The meteorological stations used in the present study are listed in Table 1 and mapped in Fig. 1. While for the future, the snow projections are based on gridded snow data produced from gridded precipitation and temperature. 


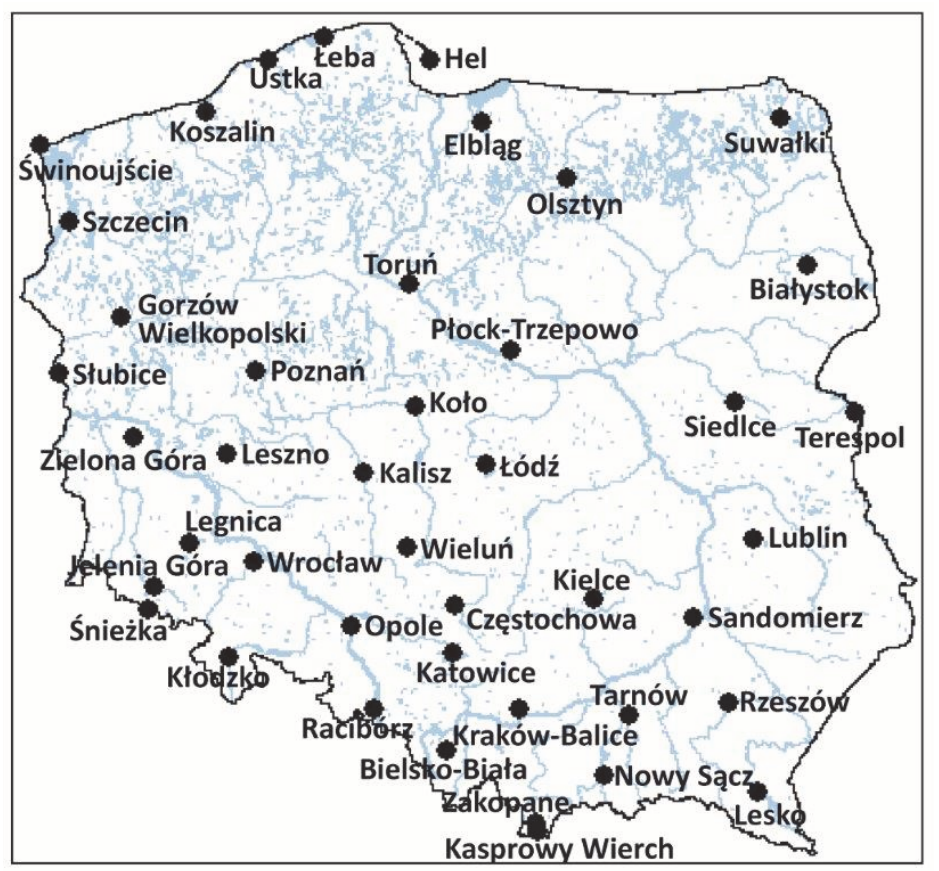

Fig. 1. Map of locations of meteorological stations used in the study.

Table 1. List of meteorological stations used in the study

\begin{tabular}{|c|c|c|c|c|c|c|c|}
\hline$\overline{\text { Station }}$ & $\begin{array}{c}\text { Lati- } \\
\text { tude } \\
\mathrm{N} \\
\end{array}$ & $\begin{array}{c}\begin{array}{c}\text { Longi- } \\
\text { tude } \\
\text { E } \\
\end{array} \\
\end{array}$ & $\begin{array}{c}\begin{array}{c}\text { Eleva- } \\
\text { tion } \\
\text { [m.a.s.l. }]\end{array} \\
\end{array}$ & "Station & $\begin{array}{c}\text { Lati- } \\
\text { tude } \\
\mathbf{N} \\
\end{array}$ & 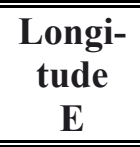 & $\begin{array}{c}\text { Eleva- } \\
\text { tion } \\
\text { [m.a.s.l.] }\end{array}$ \\
\hline Białystok & $53^{\circ} 06^{\circ}$ & $23^{\circ} 10^{6}$ & 148 & Olsztyn & $53^{\circ} 46^{6}$ & $20^{\circ} 25^{\prime}$ & 133 \\
\hline $\begin{array}{l}\text { Bielsko-Biała- } \\
\text { Aleksandrowice }\end{array}$ & $49^{\circ} 48^{\circ}$ & $19^{\circ} 00^{\varsigma}$ & 398 & Opole & $50^{\circ} 40^{‘}$ & $17^{\circ} 58^{‘}$ & 176 \\
\hline Częstochowa & $50^{\circ} 49^{‘}$ & 19 & ${ }^{\circ} 06^{\prime} 295$ & Płock-Trzepowo & $52^{\circ} 35^{\circ}$ & $19^{\circ} 44^{\circ}$ & 106 \\
\hline Elbląg-Milejewo & $54^{\circ} 10^{\circ}$ & $19^{\circ} 26^{6}$ & 38 & Poznań & $52^{\circ} 25^{\circ}$ & $16^{\circ} 50^{\circ}$ & 86 \\
\hline $\begin{array}{l}\text { Gorzów } \\
\text { Wielkopolski }\end{array}$ & $52^{\circ} 45^{\circ}$ & $15^{\circ} 17^{\natural}$ & 72 & $\begin{array}{l}\text { Racibórz- } \\
\text { Studzienna }\end{array}$ & $50^{\circ} 05^{‘}$ & $18^{\circ} 13^{‘}$ & 190 \\
\hline Hel & $54^{\circ} 36^{\circ}$ & $18^{\circ} 49^{\circ}$ & 1 & Rzeszów-Jasionka & $50^{\circ} 06^{\varsigma}$ & $22^{\circ} 03^{‘}$ & 200 \\
\hline Jelenia Góra & $50^{\circ} 54^{\circ}$ & $15^{\circ} 48^{\circ}$ & 342 & Sandomierz & $50^{\circ} 42^{‘}$ & $21^{\circ} 43^{\circ}$ & 217 \\
\hline Kalisz & $51^{\circ} 44^{\circ}$ & $18^{\circ} 05^{`}$ & 140 & Siedlce & $52^{\circ} 11^{\circ}$ & $22^{\circ} 16^{\circ}$ & 146 \\
\hline Kasprowy Wierch & $49^{\circ} 14^{\circ}$ & $19^{\circ} 59^{\circ}$ & 1991 & Słubice & $52^{\circ} 21^{\circ}$ & $14^{\circ} 36^{\circ}$ & 21 \\
\hline Katowice & $50^{\circ} 29^{\prime}$ & $19^{\circ} 05^{\varsigma}$ & 317 & Suwałki & $54^{\circ} 08^{‘}$ & $22^{\circ} 57^{`}$ & 184 \\
\hline Kielce-Suków & $50^{\circ} 51^{\circ}$ & $20^{\circ} 37^{`}$ & 268 & Szczecin-Dąbie & $53^{\circ} 24^{\circ}$ & $14^{\circ} 37^{\circ}$ & 1 \\
\hline Kłodzko & $50^{\circ} 26^{\circ}$ & $16^{\circ} 39^{\prime}$ & 316 & Śnieżka & $50^{\circ} 44^{‘}$ & $15^{\circ} 44^{\prime}$ & 1603 \\
\hline Koło & $52^{\circ} 12^{\prime}$ & $18^{\circ} 40^{\circ}$ & 116 & Świnoujście & $53^{\circ} 55^{\circ}$ & $14^{\circ} 14^{\prime}$ & 6 \\
\hline Koszalin & $54^{\circ} 12^{\prime}$ & $16^{\circ} 09^{\circ}$ & 33 & Tarnów & $50^{\circ} 02^{\circ}$ & $20^{\circ} 59^{\circ}$ & 209 \\
\hline Kraków-Balice & $50^{\circ} 05^{\varsigma}$ & $19^{\circ} 48^{\circ}$ & 237 & Terespol & $52^{\circ} 04^{\circ}$ & $23^{\circ} 37^{`}$ & 133 \\
\hline Legnica & $51^{\circ} 13^{\circ}$ & $16^{\circ} 10^{\circ}$ & 122 & Toruń & $53^{\circ} 03^{\circ}$ & $18^{\circ} 35^{\prime}$ & 69 \\
\hline Lesko & $49^{\circ} 28^{\prime}$ & $22^{\circ} 20^{‘}$ & 386 & Ustka & $54^{\circ} 35^{\circ}$ & $16^{\circ} 52^{‘}$ & 6 \\
\hline Leszno-Strzyżewice & $51^{\circ} 50^{\circ}$ & $16^{\circ} 32^{\prime}$ & 91 & Wieluń & $51^{\circ} 13^{\circ}$ & $18^{\circ} 35^{\circ}$ & 195 \\
\hline Lublin-Radawiec & $51^{\circ} 13^{\circ}$ & $22^{\circ} 24^{\circ}$ & 238 & Wrocław & $51^{\circ} 06^{\circ}$ & $16^{\circ} 53^{\prime}$ & 120 \\
\hline Łeba & $54^{\circ} 45^{\circ}$ & $17^{\circ} 32^{‘}$ & 2 & Zakopane & $49^{\circ} 18^{6}$ & $19^{\circ} 57^{‘}$ & 857 \\
\hline Łódź-Lublinek & $51^{\circ} 44^{\circ}$ & $18^{\circ} 24^{\circ}$ & 187 & Zielona Góra & $51^{\circ} 56^{\circ}$ & $15^{\circ} 30^{\circ}$ & 180 \\
\hline Nowy Sącz & $49^{\circ} 37^{\circ}$ & $20^{\circ} 42^{\prime}$ & 292 & & & & \\
\hline
\end{tabular}


For the present two characteristics, namely: (i) mean value of snow cover depth for winter (December-January-February), in cm, where the mean value is computed for all days in the given period, including days with no snow cover, and (ii) maximum value of snow cover depth for winter (December-JanuaryFebruary), in cm, were extracted from the time series of daily depth of snow cover.

To describe the observed temporal changes in snow cover characteristics for every station, the rate of change per year for the whole analyzed period was calculated, using linear regression, and the Mann-Kendall statistic. In order to detect existing changes/trends in time series of snow cover data, the Hydrospect 2.0 software was used (Radziejewski and Kundzewicz, 2000).

Few studies have been carried out for Poland based on the newest generation of climate model simulations, i.e., the fifth generation of the Coupled Model Intercomparison Project (CMIP5) and the European domain of the Coordinated Downscaling Experiment Initiative (Euro-CORDEX). In this paper a set of regional climate model simulations (Table 2) from the EuroCORDEX experiment (Jacob et al., 2014) was selected to provide climate projections. These projections can be seen as an update of old scenarios. With the aim of producing reliable high-resolution climate projections of precipitation and temperature for Poland, the output of the projections were bias-adjusted and downscaled to $5 \mathrm{~km}$. They were then used as input data to the snow model in order to transform daily temperature and precipitation into daily snow conditions. More details on these bias-adjusted climate projections are given in Mezghani et al. (2016). The data is publicly available at http://dx.doi.org/10.4121/uuid:e940ec1a-71a0-449e-bbe3-29217f2ba31d.

Projected seasonal snow cover depth (for winter as well as spring and autumn) was simulated by the snow model for the near (2021-2050) and far (2071-2100) future horizon. In order to produce unbiased snow cover projections across Poland, two experiments assumed to the two targeted radiative forcing values of $+4.5 \mathrm{Wm}^{-2}$ and $+8.5 \mathrm{Wm}^{-2}$ in 2100 (RCP4.5 and $\mathrm{RCP} 8.5)$ relative to pre-industrial values were used. 
Table 2. List of available GCM-run-RCM combinations composing the multi-model ensemble, based on EURO-CORDEX, used in determination of projections

\begin{tabular}{ll}
\hline \hline GCM & RCM \\
\hline \hline CNRM-CERFACS-CNRM-CM5 & CLMcom-CCLM4-8-17 \\
CNRM-CERFACS-CNRM-CM5 & SMHI-RCA4 \\
ICHEC-EC-EARTH & CLMcom-CCLM4-8-17 \\
ICHEC-EC-EARTH & SMHI-RCA4 \\
ICHEC-EC-EARTH & KNMI-RACMO22E \\
ICHEC-EC-EARTH & DMI-HIRHAM5 \\
IPSL-IPSL-CM5A-MR & SMHI-RCA4 \\
MPI-M-MPI-ESM-LR & CLMcom-CCLM4-8-17 \\
MPI-M-MPI-ESM-LR & SMHI-RCA4 \\
\hline
\end{tabular}

The seNorge snow model has been developed since 2004 at the Norwegian Water Resources and Energy Directorate (NVE), in cooperation with the Norwegian Meteorological Institute (MET Norway), and the Norwegian Mapping Authority (Engeset et al., 2004; Saloranta, 2014). It simulates different snow-related variables, such as snow water equivalent, snow depth, bulk snow density, and the amount of liquid water in the snow-pack. No optimization of the seNorge snow model was made for the Polish conditions, so the default set of model parameters (the same as for Norway) was used. The description of the seNorge model and a statistical evaluation of simulating snow maps for Norway in Saloranta (2012) showed that a first model version generally overestimated the snow water equivalent and the snow bulk density. In this work, we are using an updated model version (v1.1.1), where the significant biases in snow water equivalent and bulk density have been removed (Saloranta, 2014, 2016). However, only the snow depth is analyzed in this study and a separate validation based on observed snow depth in Poland is carried out.

\section{Validation}

For validation purposes, the snow model was used to simulate past snow depth across Poland, based on daily mean temperature and precipitation. The mean daily temperature values were calculated as the average of the daily minimum and maximum temperatures. 
Figs. $2 a$ and $2 b$ show the average and the total winter maximum snow depth over Poland taken from the gridded observational data set CPLFD-GDPT5 (Mezghani et al., 2016). The patterns and values agree with observation-based data for the time period 1948-49 to 1997-98 given in Falarz (2004) with the lowest average maximum depths in western Poland $(\leq 15 \mathrm{~cm})$, growing towards the northeast to $30 \mathrm{~cm}$, and exceeding $150 \mathrm{~cm}$ in the Tatra Mountains. The absolute simulated maximum winter snow depth ranges from below $40 \mathrm{~cm}$ in the west (and around Legnica) to more than $80 \mathrm{~cm}$ in the northeast, and finally, to more than $200 \mathrm{~cm}$ in the high mountains. Again, these values are in good agreement with those given in Falarz (2004) and Szwed et al. (2017).

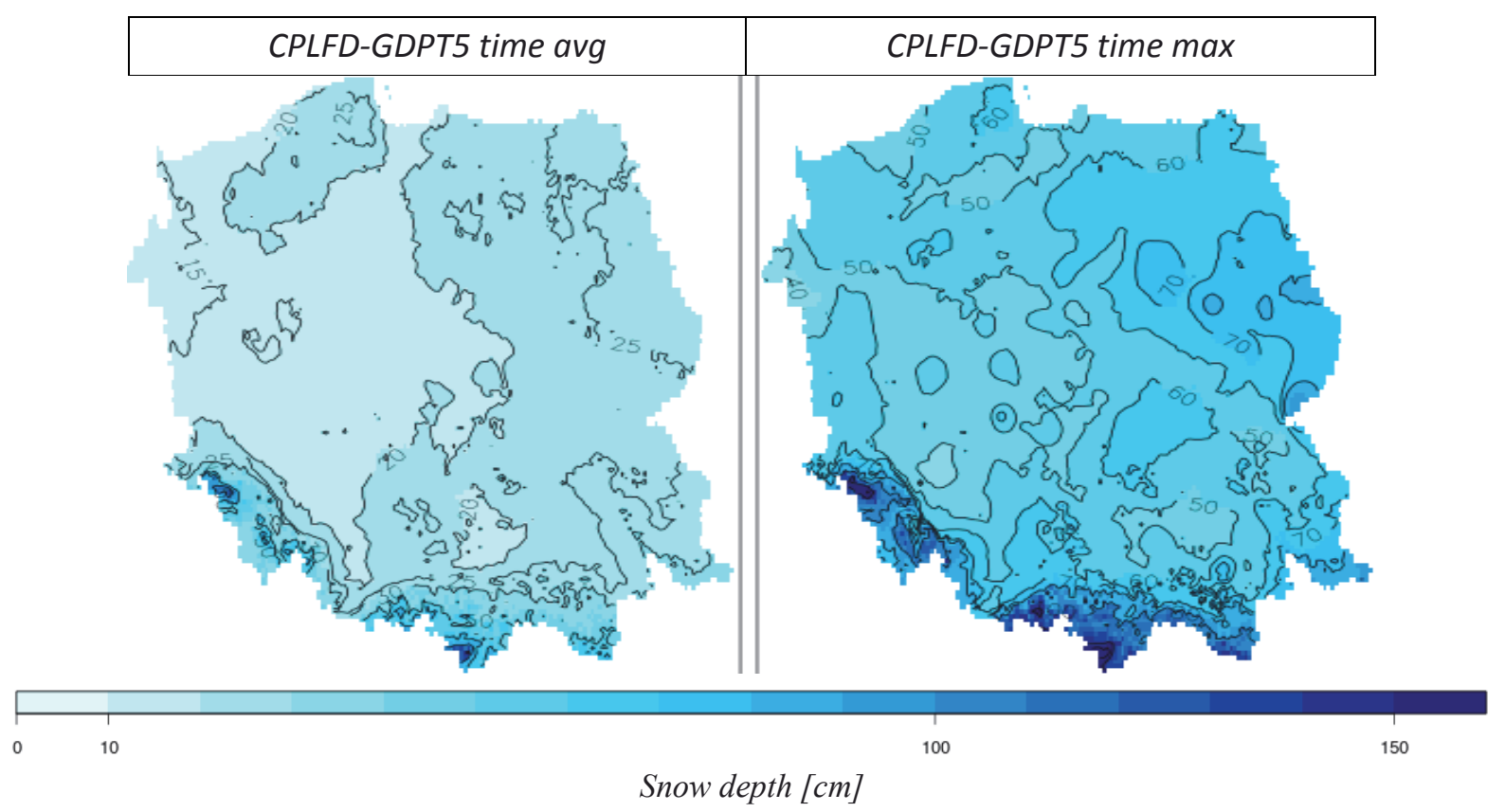

Fig. 2. Winter maximum of snow depth [cm] modeled by the seNorge model with input from the gridded CHASE-PL data set for the historical period. a) shows the time averages, while b) depicts the maximum values over all winters.

The seNorge snow model was also used with bias-adjusted precipitation and temperature values from all nine historical GCM/RCM (General Circulation Models, Regional Climate Models) runs (Table 2). Figs. $3 a$ and $3 b$ show the average and the total winter maximum snow depth over Poland for the resulting multi-model ensemble mean for 1971-2000. For the average maximum depths, the patterns and values agree again with the observation-based data shown in Fig. 2 and in Falarz (2004). The absolute maximum winter snow depth in the 
multi-model ensemble mean shows values below $40 \mathrm{~cm}$ in the west and above $200 \mathrm{~cm}$ in the Tatra Mountains as well, but has a less pronounced increase towards the northeast. However, using the mean of several climate models is expected to smooth out some of the local gradients, which can be clearly seen for a single model (not shown). As expected, the mean pattern resembles the results from the CPLFD-GDPT5-driven snow model, as the same data has been used to bias-adjust temperatures and precipitation in the model data. However, the agreement of the simulations of past conditions via RCM and the observation-driven snow depth provide a simple test for physically-consistent sequences of precipitation and temperature data in the bias-adjusted RCM data, since non-physical combinations are expected to yield unrealistic snow depths. This also demonstrates that the dependency between precipitation and temperature has been well captured by the simulations (e.g., sequence of consecutive warm dry days and cold wet days that may have a strong influence on the snow simulations) and not critically altered by the bias-adjustment methods used.

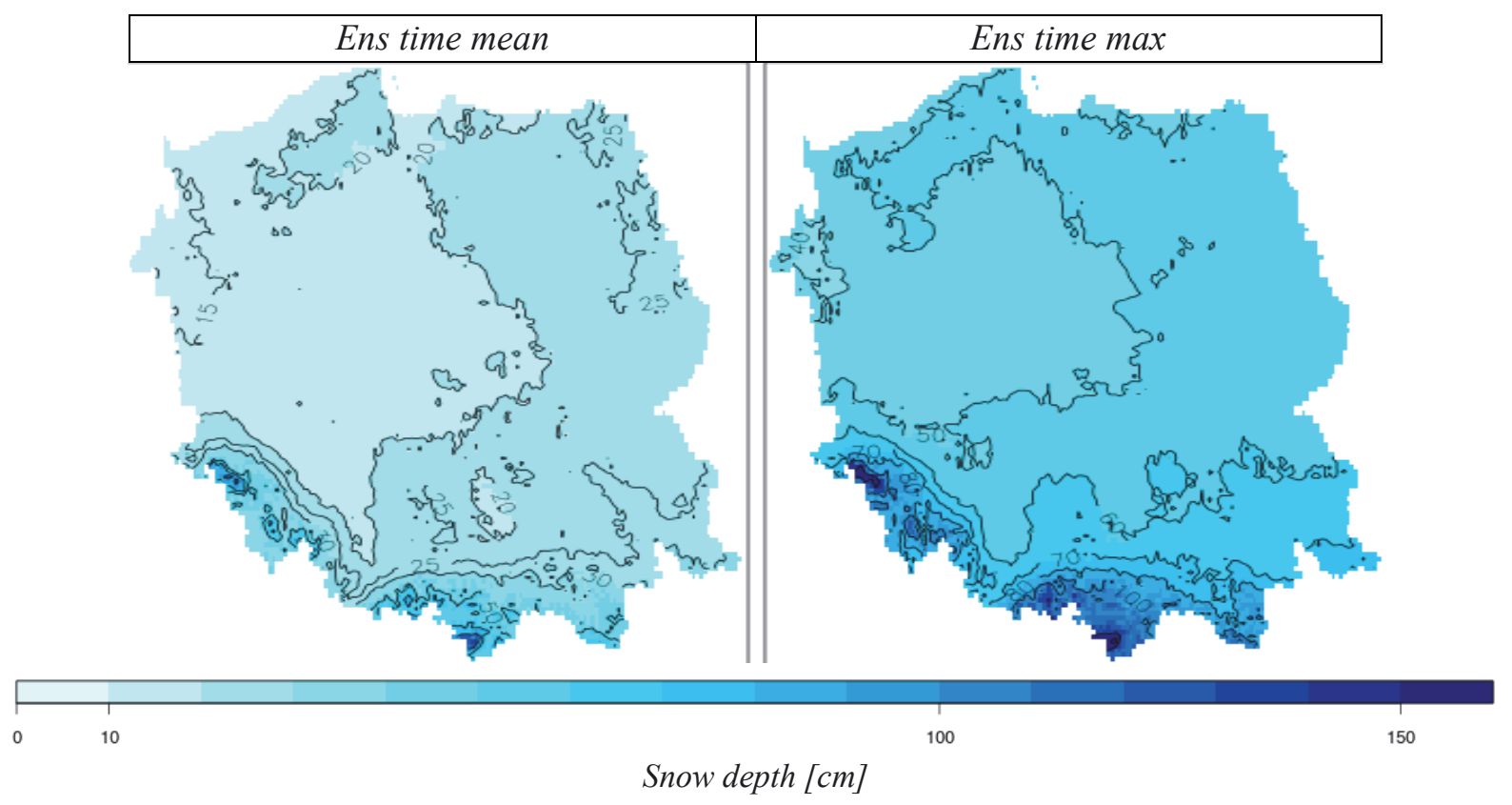

Fig. 3. Winter maximum of snow depth $[\mathrm{cm}]$ modeled by the seNorge model with input from the nine DD models for the historical period. Only the multi-model ensemble mean is shown. a) depicts the time averages, while b) shows the maximum values over all winters. 


\section{Present parameters of snow cover}

Strong inter-winter and intra-winter variability of snow cover is typical for the Polish climate. A single year can make a real difference. This statement is correct for the average snow cover, but for the maximum cover it is even more expressed. The graphs of mean and maximum depth of snow cover in winter (DJF) in Torun, Poland (Fig. 4 and 5) can serve as interesting examples. The difference between the lowest and the highest value in the time series of maximum snow cover depth is almost twice higher than for the time series of average depth of snow cover.

In the period of 1952-2013, the spatial variability of the maximum depth of snow cover in DJF in Poland changed on the east-west axis, generally increasing from the west to the east (northeast). The maximum depth of snow cover in winter (DJF) in the period 1952-2013 in Poland varied from $34 \mathrm{~cm}$ in Poznan and Słubice to $85 \mathrm{~cm}$ in Kraków (while in mountain areas, the maximum depth of snow cover exceeded $300 \mathrm{~cm}$ ).

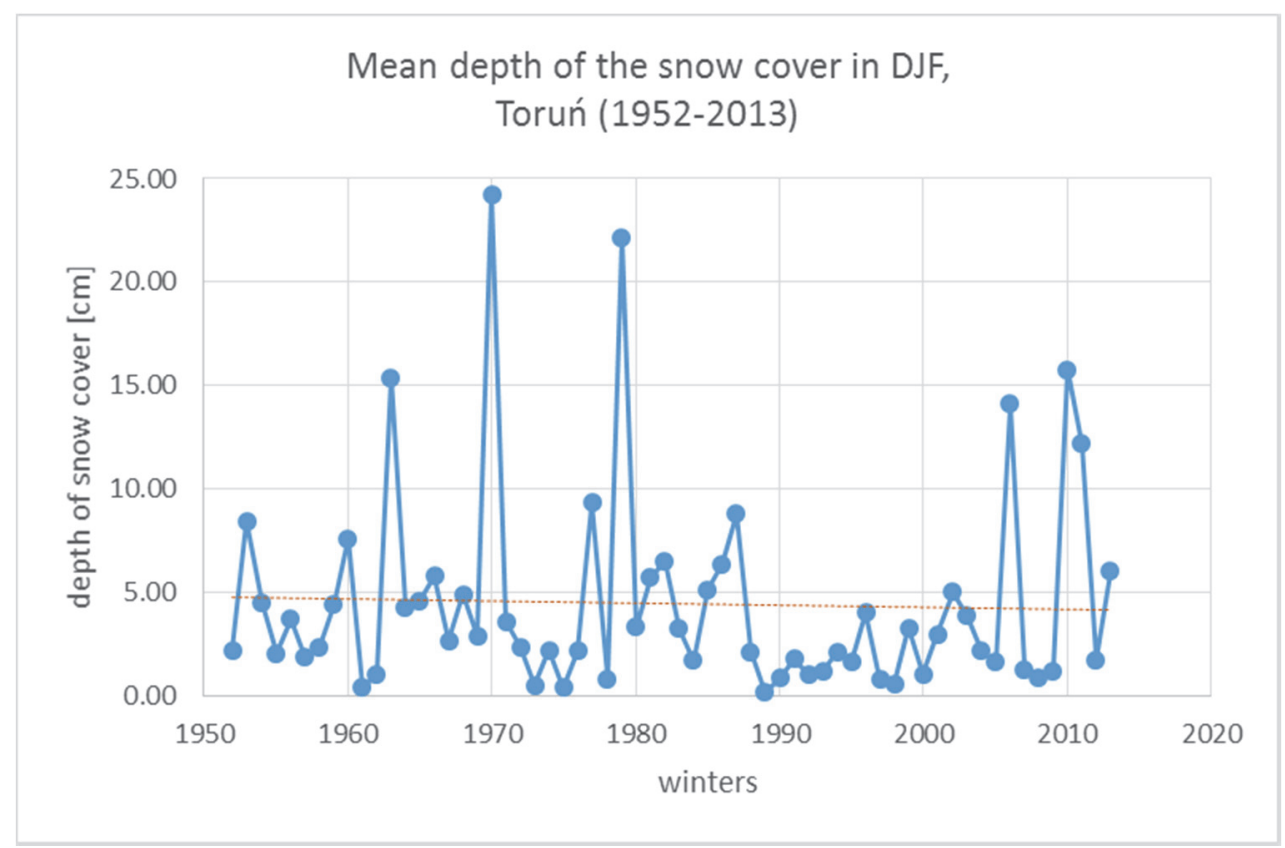

Fig. 4. Mean depth of snow cover in winter (DJF) in Torun in the period 1952-2013. 


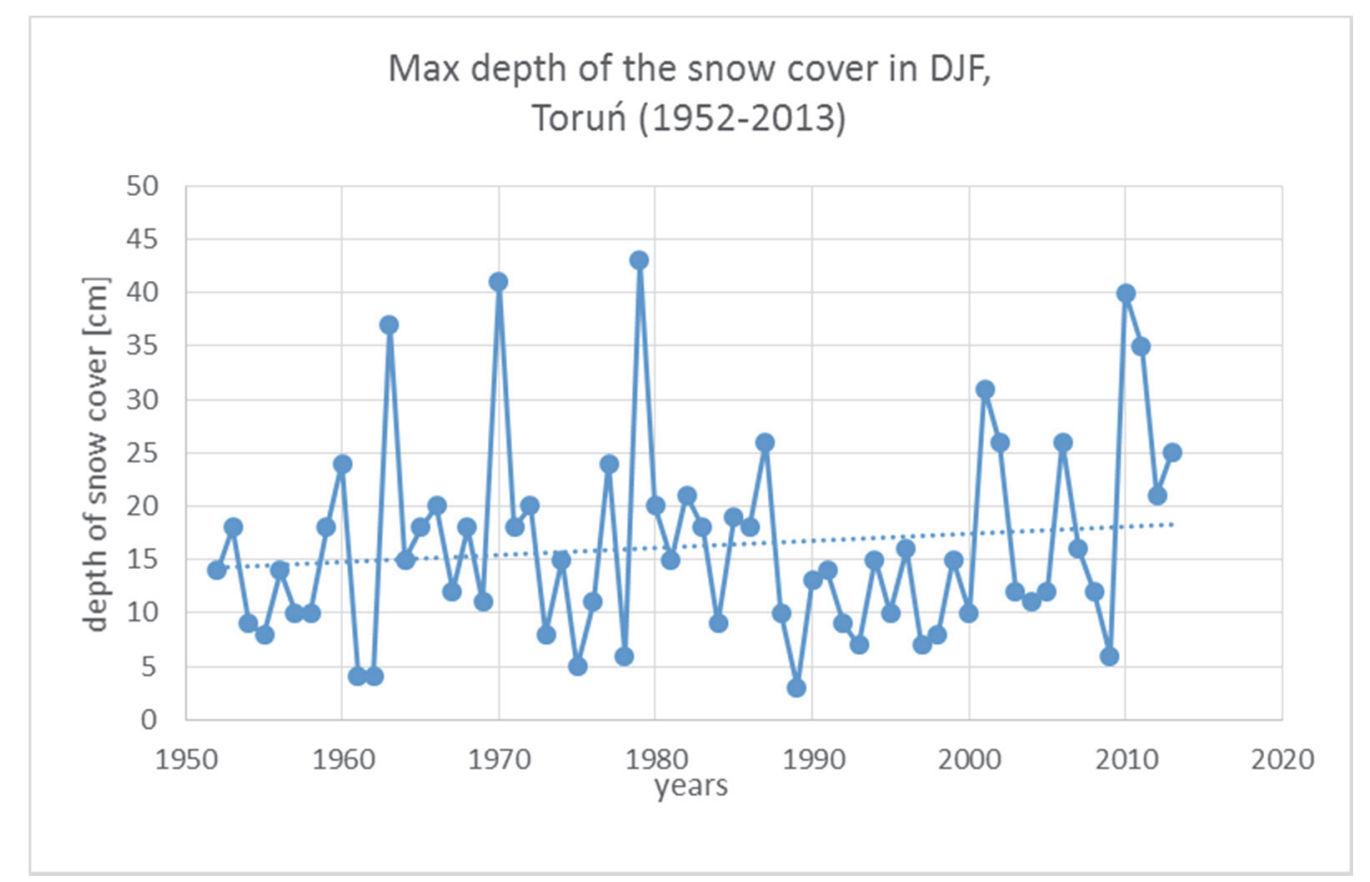

Fig. 5. Maximum depth of snow cover in winter (DJF) in Torun in the period 1952-2013.

Observed behavior of time series of snow cover depth is complex and not easy to interpret. All tendencies are overshadowed by strong natural inter-annual variability, making trend detection unlikely. Indeed, no significant trend on the 0.05 level was detected for all part of the country (based on Mann-Kendall test). The weak tendencies in the snow-cover depth are location-specific, the value of change per year is positive at some locations, while negative at others. However, as expected in the warming climate, there are many more locations with a negative tendency (25) than with a positive one (15). In general, after 1990, a cluster of years with shallow snow cover have occurred. Nevertheless, more snowy winters (with higher depth of mean and maximum snow cover) have also appeared more recently. The winter of 1963 and 1979 (i.e., December 1962 February 1963, and December 1978 - February 1979, respectively) are the absolute record holders. In these years, maximum of snow cover depth occurred for 13 and 12 stations (of 43), respectively. Temporal changes in maximum depth of snow cover in winter (DJF) in the period 1952-2013, expressed by the rate of change per year and the statistical significance level are presented in Fig. 6. 


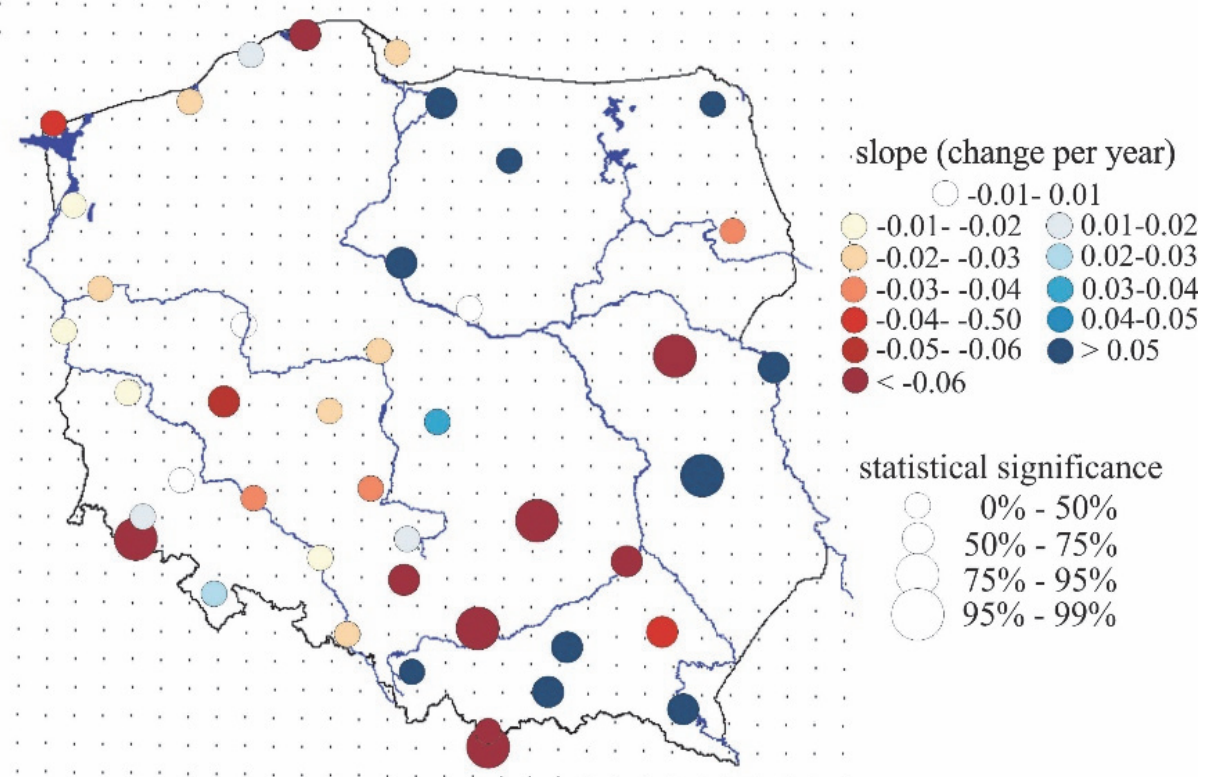

Fig. 6. Temporal changes in maximum depth of snow cover in winter (DJF) in the period 1952-2013 expressed by the rate of change per year and the statistical significance level.

\section{Projection of snow cover}

Table 3 summarizes the projected seasonal snow depth (for winter DJF as well as spring MAM and autumn SON) as simulated by the seNorge snow model by using the bias-adjusted daily projections in the near (NF) and far (FF) future. As an indicator of snow change conditions, the maximum seasonal snow depth is used and analyzed hereafter.

Table 3. Relative changes in maximum seasonal snow depth (\%) from snow modeling based on bias-corrected RCM data. The corresponding ensemble mean absolute values in centimeters are also given. Confidence limits are presented in parentheses.

\begin{tabular}{ccccc}
\hline \hline RCP & Future horizon & DJF & MAM & SON \\
\hline \hline \multirow{3}{*}{ RCP4.5 } & NF & $-15 ;-10 \mathrm{~cm}$ & $-14 ;-9 \mathrm{~cm}$ & $-25 ;-5 \mathrm{~cm}$ \\
& $2021-2050$ & $(-27 ; 5)$ & $(-33 ; 9)$ & $(-37 ;-11)$ \\
\cline { 2 - 5 } & FF & $-28 ;-18 \mathrm{~cm}$ & $-34 ;-21 \mathrm{~cm}$ & $-18 ;-4 \mathrm{~cm}$ \\
& $2071-2100$ & $(-44 ;-13)$ & $(-56 ;-15)$ & $(-50 ; 10)$ \\
\hline \multirow{2}{*}{ RCP8.5 } & NF & $-20 ;-12 \mathrm{~cm}$ & $-21 ;-13 \mathrm{~cm}$ & $-20 ;-4 \mathrm{~cm}$ \\
& $2021-2050$ & $(-33 ;-9)$ & $(-45 ;-1)$ & $(-47 ; 3)$ \\
\cline { 2 - 5 } & FF & $-44 ;-27 \mathrm{~cm}$ & $-60 ;-37 \mathrm{~cm}$ & $-48 ;-10 \mathrm{~cm}$ \\
& $2071-2100$ & $(-64 ;-24)$ & $(-87 ;-33)$ & $(-81 ;-23)$ \\
\hline
\end{tabular}


Fig. 7 shows the maximum annual snow depth projections by the two future horizons: NF 2021-2050 and FF 2071-2100 (rows) in comparison to the reference interval 1971-2000, following two RCPs (representative concentration pathways) 4.5 and 8.5 (columns). Projections suggest that the maximum snow depth is expected to decrease by the two future horizons and following two RCPs. This decreasing rate is expected to be about $15 \%$ and about $20 \%$, under RCP 4.5 and RCP 8.5 by 2021-2050, respectively.

This rate of decreasing maximum snow depth is expected to double by 2071-2100, regardless the RCP, and may go down to more than $40 \%$ under RCP8.5, compared to reference values. Nevertheless, even if most areas in Poland are expected to get affected, changes in central areas are less pronounced. This may be explained by the convergence of different physical processes influencing the snow conditions in those areas. In addition, small areas of increases may also occur in the near future, mainly in high mountainous regions. This is understandable in the light of increased precipitation in the warming climate. This can mean more snow fall if the increased temperature does not substantially exceed $0{ }^{\circ} \mathrm{C}$.
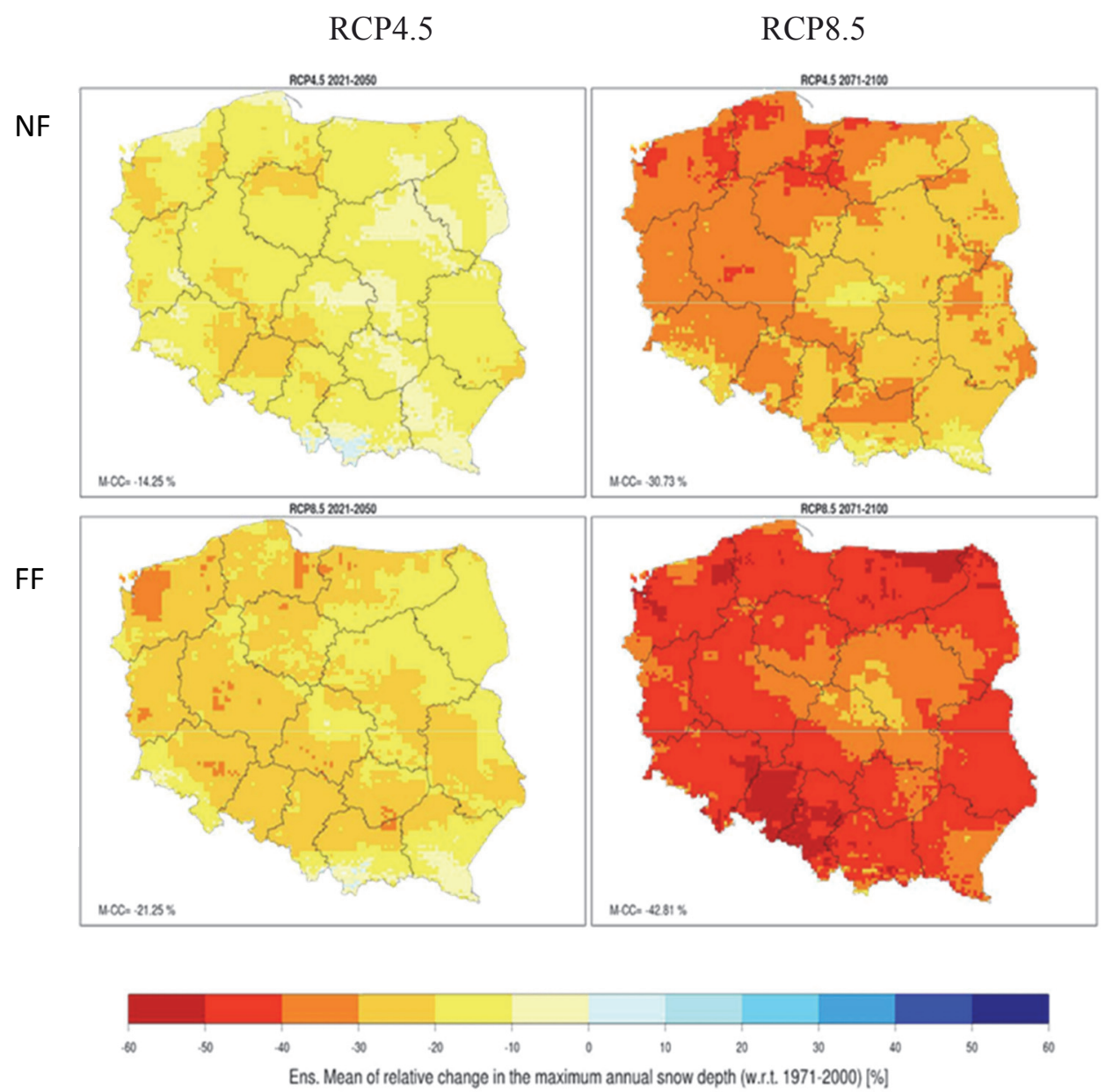

Fig. 7. Maximum snow depth projections for two horizons:NF 2021-2050 and FF 20712100 (in the rows) under two RCPs: 4.5 and 8.5 (in the columns). 


\section{Conclusions}

Observed variability of maximum depth of snow cover in Poland, based on a set of 43 time series of station records, as well as projections for two future horizons were examined. Snow projections were obtained with the help of the seNorge snow model, fed with high-resolution climate (precipitation and temperature) projections.

Even if decrease of total annual snowfall and snow cover depth are expected in the warming climate, observed behavior of time series of records is complex and not easy to interpret. Eventual tendencies are overshadowed by the strong natural inter-annual variability, making significant trend detection unlikely. There were some winters with very high or very low snow cover depth. For instance, winter of 1963 and 1979 (i.e., December 1962 - February 1963 and December 1978 - February 1979, respectively) are the absolute record holders, because maximum of snow cover depth occurred there for 13 and 12 stations, respectively.

There are weak and location-specific tendencies in snow-cover depth, but no significant trend on the 0.05 level was detected for all part of the country (based on Mann-Kendal test). However, as expected in the warming climate, there are many more locations with a negative tendency than with a positive one. This corresponds with many other research studies concerning Europe, which report large variability between individual seasons, and the lack of distinct, statistically significant trends, e.g., for Estonia (Jaagus, 1997) or Slovakia (Brown and Petkova, 2007). A slight decreasing trend of snow cover depth was observed in most areas of Poland during the second half of the 20th century, but no change was distinguished for the longer periods (Falarz 2004; Nowosad and Bartoszek 2007; Czarnecka 2012).

Maximum depth of snow cover in winter (DJF) in the Polish high mountains is going to decrease. Lapin and Fasko (2005) reveal for a decrease in snow cover conditions in the Little Carpatians after 1990. Similar conclusions were reached by Brown and Petkova (2007) for Bulgarian mountainous regions. Research for central and north Tyrol identifies a minor decreasing snow depth trend during 1895-1991 (Fliri and Baumkirchen, 1991), while Beniston (1997) confirms a considerable decrease of snow cover since the mid-1980s in the Swiss Alps. Falarz (2004) quotes that an increasing trend in snow cover has been noted during the second half of the 20th century in Polish mountainous regions.

Projected seasonal snow cover depth, as simulated by the seNorge snow model show ubiquitous decreases for both the near and far future. The rate of decreasing maximum snow depth is expected to at least double by 2071-2100.

However, small areas of increases of snow cover depth may still occur in near future in high mountainous areas in the south part of Poland, accompanying precipitation increase in the warming climate. If the increased temperature does 


\title{
not substantially exceed $0{ }^{\circ} \mathrm{C}$, snow can be the essential component of increased winter precipitation.
}

\begin{abstract}
Acknowledgments: Support of the project CHASE-PL (Climate change impact assessment for selected sectors in Poland) of the Polish-Norwegian Research Programme operated by the National Centre for Research and Development (NCBiR) under the Norwegian Financial Mechanism 20092014 in the frame of Project Contract No. Pol Nor/200799/90/2014 is gratefully acknowledged. The source of meteorological data is the Institute of Meteorology and Water Management - National Research Institute (IMGW-PIB). Data of the Institute of Meteorology and Water Management National Research Institute have been processed. We also acknowledge the World Climate Research Programme's Working Group on Regional Climate, and the Working Group on Coupled Modelling, former coordinating body of CORDEX and responsible panel for CMIP5, and want to thank the climate modelling groups (listed in Table 1 of this paper) for producing and making available their model output. We also acknowledge the Earth System Grid Federation infrastructure an international effort led by the U.S. Department of Energy's Program for Climate Model Diagnosis and Intercomparison, the European Network for Earth System Modelling, and other partners in the Global Organisation for Earth System Science Portals (GO-ESSP).
\end{abstract}

\section{References}

Beniston, M., 1997: Variations of snow depth and duration in the Swiss Alps over the last 50 years: links to changes in large-scale climatic forcings. Climatic Change 36, 281-300.

https://doi.org/10.1007/978-94-015-8905-5_3

Brown, R.D. and Petkova, N., 2007: Snow cover variability in Bulgarian mountainous regions, 19312000. Int. J. Climatol., 27, 1215-1229. https://doi.org/10.1002/joc.1468

Czarnecka, M., 2012: Częstość występowania i grubość pokrywy śnieżnej w Polsce. Acta Agrophysica, 19, 501-514. (In Polish)

Engeset, R., Tveito, O.E., Udnoes, H.-C., Alfnes E., Mengistu, Z., Isaksen, K., and Førland E.J., 2004: Snow map validation for Norway. XXIII Nordic Hydrological Conference. Tallinn, Estonia. NHP report, 48(1), 122-131.

Falarz, M., 2004: Variability and trends in the duration and depth of snow cover in Poland in the 20th century. Int. J. Climatol. 24, 1713-1727. https://doi.org/10.1002/joc.1093

Fliri, F. and Baumkirchen, H., 1991: Die Schneeverhaltnisse in Nord- und Osttirol in der Periode 1895-1991. Mitteilungen der Osterreichischen Geographischen Gesellschaft 133, 7-25. (In German)

Jacob, D., Petersen, J., Eggert, B., Alias, A., Christensen, O.B., Bouwer, L.M., Braun, A., Colette, A., Déqué, M., Georgievski, G. and Georgopoulou, E., 2014: EURO-CORDEX: new highresolution climate change projections for European impact research Reg. Environ. Change 14, 563-578. https://doi.org/10.1007/s10113-013-0499-2

Jaagus, J., 1997: The impact of climate change on the snow cover pattern in Estonia. Climatic Change 36, 65-77. https://doi.org/10.1023/A:1005304720412

Lapin, M., and Faško, P., 2005: Snow cover changes in the Little Carpathians in Slovakia. In Online Proceedings of ICAM2005, 28th International Conference on Alpine Meteorology, Zadar, Croatia, 23-27 May 2005, s. 658-661. http://meteo.hr/ICAM2005/

Mezghani, A., Dobler, A., and Haugen, J.H., 2016: CHASE-PL Climate Projections: 5-km Gridded Daily Precipitation \& Temperature Dataset (CPLCP-GDPT5). Norwegian Meteorological Institute. Dataset. http://dx.doi.org/10.4121/uuid:e940ec1a-71a0-449e-bbe3-29217f2ba31d

Nowosad, M. and Bartoszek, K., 2007: Wieloletnia zmienność grubości pokrywy śnieżnej w okolicy Lublina. In: K. Piotrowicz, R. Twardosz (reds) Wahania klimatu w różnych skalach przestrzennych i czasowych. Instytut Geografii i Gospodarki Przestrzennej UJ Kraków, 411421. (In Polish)

Radziejewski, M., and Kundzewicz Z.W., 2000: Hydrospect - Software for detecting changes in hydrological data. In (eds.: Robson, A. and Kundzewicz Z.W.) Detecting trend and other changes 
in hydrological data, App. 2. World Climate Programme-Applications and Services, World Meteorological Organization, Geneva.

Saloranta, T.M., 2012: Simulating snow maps for Norway: description and statistical evaluation of the seNorge snow model, The Cryosphere 6, 1323-1337. https://doi.org/10.5194/tc-6-1323-2012

Saloranta, T.M., 2014: New version (v.1.1.1) of the 'seNorge' snow model and snow maps for Norway. Norwegian Water Resources and Energy Directorate, NVE report 6, 36.

Saloranta, T.M., 2016: Operational snow mapping with simplified data assimilation using the seNorge snow model. J. Hydrol. 538, 314-325. https://doi.org/10.1016/j.jhydrol.2016.03.061

Szwed, M., Pińskwar, I., Kundzewicz, Z.W., Graczyk D. and Mezghani A., 2017: Changes of snow cover in Poland. Acta Geophysica 65, 65-76. https://doi.org/10.1007/s11600-017-0007-z 